\title{
EFEKTIVITAS SISTEM MANAJEMEN MUTU ISO 9001:2008 TERHADAP KUALITAS PELAYANAN ADMINISTRASI KEPENDUDUKAN DI KOTA BLITAR
}

\author{
EFFECTIVENESS OF QUALITY MANAGEMENT SYSTEM ISO 9001:2008 OF \\ ADMINISTRATION POPULATION SERVICE QUALITY IN THE CITY BLITAR
}

\author{
Irtanto \\ Badan Penelitian dan Pengembangan Provinsi Jawa Timur \\ Jl. Gayung Kebonsari No. 56, Surabaya \\ E-mail: irtanto@ rocketmail.com \\ Diterima: 29 Oktober 2012; direvisi: 25 November 2012; disetujui: 10 Desember 2012
}

\begin{abstract}
Abstrak
Penelitian ini menggunakan pendekatan deskriptif kuantitatif, yang bertujuan (1) mengetahui efektivitas SMM ISO 9001:2008 terhadap kualitas pelayanan kependudukan; (2)mengetahui faktor-faktor yang mempengaruhi efektivitas SMM ISO 9001:200 dalam mewujudkan pelayanan berkualitas. Hasil penelitian menunjukkan bahwa analisis mengenai efektivitas SMM ISO 9001:2008 di Kota Blitar mengenai layanan administrasi kependudukan meliputi bukti langsung, kehandalan, daya tanggap aparat pelayanan, jaminan, dan empati diperoleh nilai kualifikasi rata-rata 3,18 dengan kriteria baik, tingkat pencapaian rata-rata sebesar 79,99\% dengan kriteria pencapaian efektif. Faktor yang mempengaruhi tidak efektivitasnya pelayanan disebabkan oleh karena faktor tangibel dan kenyaman pelayanan masih kurang; kehandalan petugas pelayanan yang masih kurang; akurasi dan daya tanggap petugas pelayanan perlu diperhatikan; dan masih kurangnya empati aparat, tingkat ketrampilan dan kedislipinan aparat dalam memberikan pelayanan yang masih perlu ditingkatkan, adanya biaya tambahan di luar ketentuan untuk mendapatkan pelayanan, petugas dalam memberikan pelayanan masih ada yang kurang ramah.
\end{abstract}

Kata kunci: efektivitas, kualitas pelayanan, sistem manajemen, pelayanan administrasi

\begin{abstract}
This research used quantitative descriptive approach, which aims to know (1) the effectiveness of QMS ISO 9001:2008 in realizing a population service quality (2) to know factors that influence the effectiveness of QMS ISO9001:2008 in realizing quality service. The results showed that the analysis of the effectiveness of QMS ISO 9001:2008 in Blitar City on population administration service covering direct evidence, reliability, responsiveness of service, assurance, and empathy qualifier values obtained with the 3.18 average good criteria, average achievement of $79.99 \%$ with the effective achievement criteria. The factors that affect is not effectiveness of the service caused the tangible and comfort care; reliability of service personnel; accuracy and responsiveness of care apparatus, and fempathyapparatus are lacking, the level of skill and discipline personnel in providing services to be improved, the additional costs beyond the provision for services, personnel in providing services there are less friendly.
\end{abstract}

Keywords: effectiveness, quality of service, management system, administration service

\section{PENDAHULUAN}

Demokratisasi seperti sekarang di Indonesia yang gencar-gencar di bangun berdampak luas terhadap debirokratisasi pelayanan publik, selain itu berdampak pula terhadap perubahan paradigma dalam penyelenggaraan pemerintah daerah, di massa pemerintahan orde baru lebih bersifat sentralistis kini berubah desentralistis. Organisasi pemerintah pada saat ini identik dengan organisasi pelayanan masyarakat (public service). Kondisi ini tidak lepas sebagai dampak lahirnya UU No. 32 tahun 2004 yang mempunyai konsekuensi daerah mempunyai kewenangan terhadap persoalan pelayanan publik. Hal ini mengindikasikan bahwa kualitas tidaknya pelayanan publik tergantung dari daerah itu sendiri.
Di sisi lain dewasa ini dari ke hari-hari berbagai desakan terhadap perbaikan pelayanan publik terus saja terjadi dimana-mana dan tidak mengherankan jika ekspektasi masyarakat terhadap kualitas pelayanan semakin tinggi. Oleh karenanya, pemerintah daerah dituntut melakukan berbagai inovasi terhadap pelayanan publik. Untuk meningkatkan efektivitas dan kualitas pelayanan kepada masyarakat, maka pemerintah selaku penyedia layanan harus berorientasi pada pemenuhan kebutuhan dan kepuasan masyarakat.

Dari kondisi seperti di atas perlu dijawab dengan berbagai teori untuk mengukur kualitas pelayanan publik. Sedangkan untuk mengukur dan meningkatkan kualitas pelayanan diperlukan standarisasi terhadap manajemen mutu pelayanan. Pengukuran terhadap manajemen mutu pelayanan 
menjadi suatu kebutuhan yang mendesak. Sebagai konsekuensinya, setiap organisasi pemerintah perlu menyiapkan kerangka sistem manajemen mutu organisasinya sesuai dengan tujuan dan fungsinya. Untuk itu, Pemerintah Kota Blitar terutama yang bergerak di bidang pelayanan publik tentunya secara langsung maupun tidak langsung tidak lepas dari penerapan Sistem Manajemen Mutu (SMM) ISO 9001:2008.

Tolok ukur kualitas tidaknya pelayanan birokrasi kadang-kadang bersifat subyektif, tergantung dari cara pandang masing-masing orang dalam menentukan kualitas seperti apa yang diinginkan. Pelayanan publik buruk, masyarakat belum tentu semuanya secara langsung melakukan komplain terhadap pemerintah selaku pemberi layanan, bisa saja masyarakat pasif, tidak reaktif sebagaimana pernyatan Tjiptono bahwa pelanggan yang tidak puas tidak melakukan komplain, tetapi mereka praktis tidak akan membeli atau menggunakan jasa perusahaan yang bersangkutan lagi (2000:52). Ini berbeda dengan birokrasi selaku pemegang monopoli pelayanan administrasi kependudukan, akibatnya distrust terhadap birokrasi pemerintahan akan terjadi yang berdampak luas.Pemerintahan Kota Blitar akhirakhir ini sering mendapatkan berbagai penghargaan terutama sepuluh tahun terakhir di massa dua dekade massa kepimpinan Walikota Djarot Syaiful Hidayat dari tahun 2000-2010, seperti pelayanan Puskesmas Bendogerit yang menerapkan Citizen Charter. Selain itu pelayanan kependudukan perlu dikaji dengan penerapkan SMM ISO 9001:2008 sebagai standar pengendalian mutu dalam pemberian pelayanan kependudukan. Adapun tujuan dari penelitian ini adalah mengetahui efektivitas SMM ISO 9001:2008 dalam mewujudkan kualitas pelayanan kependudukan dan bertujuan pula mengetahui faktor-faktor yang mempengaruhi efektivitas SMM ISO 9001:200 dalam mewujudkan pelayanan berkualitas.

Secara teoritik efektivitas merupakan penilaian hasil pengukuran dalam arti tercapainya tujuan yang telah ditetapkan sebelumnya. Efektivitas mempunyai efek yang besar terhadap kepentingan orang banyak (Emerson, dalam Handayaningrat, 1985:16). Efektivitas merupakan usaha pencapaian sasaran yang dikehendaki yang ditujukan kepada orang banyak dan dapat dirasakan oleh kelompok sasaran. Kemudian Siagian (1997:151) mendefinisikan bahwa efektivitas adalah sebagai penyelesaian pekerjaan tepat pada waktunya, dalam arti apakah dalam melaksanakan tugas dinilai baik atau tidaknya sangat tergantung pada kapan tugas itu terselesaikan. Pendekatan pencapaian tujuan sebagai variabel dalam mengukur efektivitas SMM 9001:2008 untuk mewujudkan pelayanan yang berkualitas. Selanjutnya pelayanan umum menurut difinisi Sianipar (1998:4) adalah segela bentuk kegiatan publik yang dilaksanakan oleh aparat pemrintah, baik di pusat, di daerah, dan lingkungan Badan Usaha Negara/daerah dalam bentuk barang dan jasa, baik dalam upaya pemenuhan kebutuhan masyarakat yang sesuai dengan harapan mreka maupun menurut ketentuan pertundang-undangan yang berlaku. Oleh karena itu pelayanan publik perlu dikaji dengan menggunakan berbagai teori tentang kualitas pelayanan yang rrelavan antara lain dengan menggunakan pengembangan teori kualitas pelayanan menurut Parasuraman (dalam Tjiptono, 2002:27) yang terdiri dari lima item penting, yaitu 1) bukti langsung (tangibles) meliputi fasilitas fisik, perlengkapan, pegawai dan sarana komunikasi; 2). Empati (emphathy) meliputi kemudahan dalam melakukan hubungan komunikasi yang baik dan memahami kebutuhan para masyarakat; 3). kehandalan (reliability), yakni kemampuan memberikan pelayanan yang dijanjikan dengan segera dan memuaskan: 4). Daya tanggap (responsiveness), yaitu keinginan para staf untuk membantu masyarakat dan memberikan pelayanan dengan tanggap; 5). Jaminan (assurance), mencakup kemampuan, kesopanan, dan sikap yang dapat dipercaya yang memiliki para staf, bebas dari bahaya, resiko atau keragu-raguan". Selanjutnya teori Vincent Gespersz (dalam Lukman, 2003) hampir relatif sama dengan teori Parasuraman, bahwa demensi kualitas pelayanan antara lain 1 . Ketepatan waktu pelayanan; 2. Akurasi pelayanan; ; hal ini berkaitan dengan keakuratan pelayanan dan bebas dari kesalahan-kesalahan; 3. Kesopanan dan keramahan dalam memberikan pelayanan; berkaitan dengan perilaku orang-orang yang berinteraksi langsung kepada masyarakat eksternal; 4. Tanggung jawab; berkaitan dengan penerimaan pesanan dan penanganan pengaduan dari masyarakat ekternal (masyarakat); 5. Kemudahan mendapatkan pelayanan; berkaitan dengan banyaknya petugas yang melayani dan fasilitas pendudukun; 6. Kenyaman dalam memperoleh pelayanan pelayanan; berkaitan dengan lokasi, ruangan tempat pelayanan, tempat parkir, ketersediaan informasi, dan petunjuk panduan lainnya.

Di sisi lain masyarakat mempunyai harapan terhadap pelayanan publik, menurut Moenir (2001:41) ada empat hal, yaitu (1) Adanya kemudahan dalam pengurusan kepentingan dengan pelayanan yang cepat dalam arti tanpa hambatan yang kadang-kadang dibuat-buat; (2) Memperoleh pelayanan yang wajar tanpa gerutu, sindirian atau untaian kata lain semacam itu yang nadanya mengarah pada permintaan sesuatu, baik dengan alasan untuk dinas; (3) Mendapatkan perlakuan yang sama, tertib, dan tidak pandang bulu; (4) Pelayanan yang jujur dan terus terang, artinya apabila ada hambatan karena suatu masalah yang tidak dapat dielakkan hendaknya diberitahukan sehingga orang tidak menunggu-menunggu sesuatu yang tidak menentu.

Sedangkan tujuan penelitian ini adalah mengetahui efektivitas SMM ISO 9001:2008 dalam mewujudkan pelayanan berkualitas administrasi kependudukan Kota Blitar dan mengidentifikasi berbagai faktor yang mempengaruhi efektivitas SMM ISO 9001:200 dalam mewujudkan pelayanan berkualitas administrasi kependudukan di Kota Blitar. 
Berbagai teori dan tujuan penelitian yang hendak diteliti dapat digambarkan dalam kerangka penelitian sebagaimana tersebut dibawah ini. dilakukan dalam analisis data pada penelitian ini meliputi: (1) Menyeleksi data; (2) Klasifikasi data; (3) Tabulasi data; (4) Standarisasi data. Ada dua

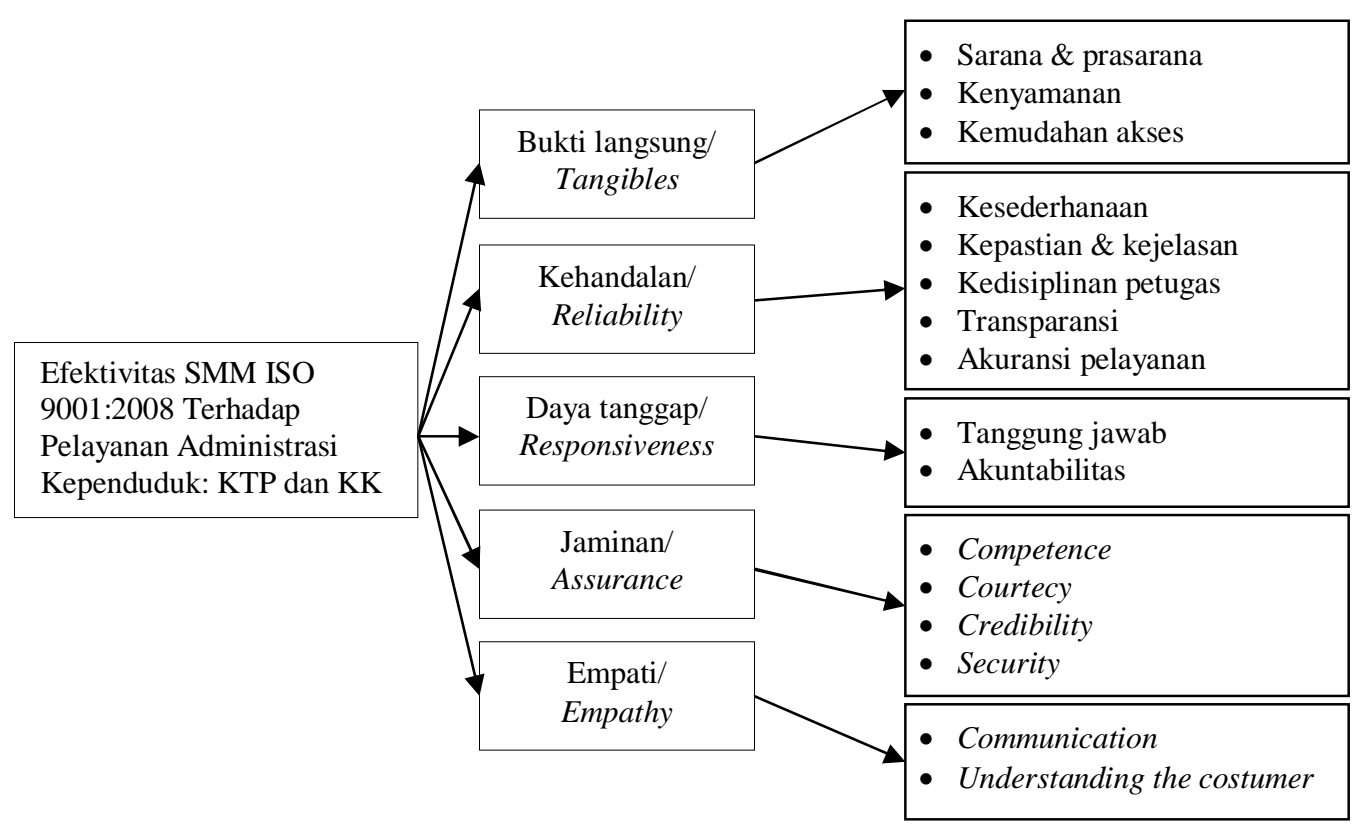

Gambar 1. Kerangka Penelitian.

\section{METODE PENELITIAN}

Pendekatan yang digunakan dalam peneltian ini deskriptif kuantitatif. Penelitian deskriptif tidak dimaksudkan untuk menguji hipotesis tertentu, tetapi hanya menggambarkan 'apa adanya' tentang suatu variabel, gejala, atau keadaan (Arikunto, 2006:68), hanya menggambarkan atau memaparkan keadaan dan obyek penelitian yang didasarkan pada data dan fakta yang ada tanpa terkait keharusan membuat hipotesis.

\section{Lokasi dan Sampel}

Lokasi penelitian di Kota Blitar yang meliputi tiga (3) kecamatan, Sananwetan, Sukorejo, dan Kecamatan Kepanjenkidul. Pengambilan sampel menggunakan pedoman dari Roscoe (1975) yang mengusulkan ukuran sampel lebih dari 30 dan kurang dari 500 adalah tepat untuk kebanyakan penelitian (dalam Uma Sekaran (2006). Pengambilan sampel masing-masing kecamatan diambil 100 orang, sampel keseluruhan sebanyak 300 orang.

\section{Teknik Pengumpulan dan Analisa Data}

Teknik pengumupulan data menggunakan kuesioner. Pilihan jawaban menggunakan 4 pilihan jawaban, mulai dari yang bermakna sangat negatif sampai yang bermakna sangat positif. Teknik wawancara kami gunakan untuk mendapatkan informasi yang lebih mendalam tentang persoalan pelayanan administrasi kependudukan.

Teknik analisa data menggunakan analisis deskriptif kuantitatif. Sedangkan tahap-tahap yang standarisasi data dalam penelitian ini, pertama untuk menentukan indikator kualitas hasil pendapat responden untuk mengukur pendapat responden mengenai kualitas pelayanan administrasi kependudukan pembuatan KTP dan KK; kedua, standarisasi data untuk persentase tingkat pencapaian dari sub variabel dan indikator untuk mengukur pendapat responden mengenai tingkat pencapaian SMM ISO 9001:2008 dengan mendeskripsikan kualitas pelayanan administrasi kependudukan. Standarisasi data tersebut ditentukan melalui: a.Penentuan kriteria penilaian pendapat responden. Kualitas jawaban ditentukan dengan skala likert, dengan memberikan 4 (empat) alternatif jawaban yang diberikan kepada responden sesuai dengan kedalaman jangkauan jawaban. Kriteria kualitas jawaban ditentukan dengan bobot nilai sebagai berikut bobot nilai tertingi 4 dan terendah 1 . b. Penentuasn nilai kualifikasi. Nilai kualifikasi tersebut ditentukan oleh jumlah dari frekuensi jawaban dikali bobot nilai kemudian dibagi dengan jumlah responden sebagaimana rumus untuk menghitungkan rata-rata menurut Nazir (2005:380) sebagai berikut:

\begin{tabular}{|c|c|c|}
\hline \multirow{2}{*}{$\begin{array}{l}\text { Nilai } \\
\text { Kualifikasi }\end{array}$} & $=$ & $\begin{array}{c}\text { Jumlah } \\
\text { (frekuensi jawaban x bobot nilai) }\end{array}$ \\
\hline & $=$ & Jumlah Responden \\
\hline & & Nilai Total \\
\hline
\end{tabular}


Selanjutnya, ditetapkan interval nilai guna mendapatkan kualifikasi interpretasi. Kemudian untuk mencari besarnya interval dengan menggunakan range dan jumlah kelas (Nazir (2005:380).

$$
\mathrm{I}=\underline{\mathrm{R}}
$$

Dimana I adalah besarnya interval, $\mathrm{R}$ adalah jarak pengukuran (nilai tertinggi-nilai terendah, dan $\mathrm{K}$ adalah jumlah kelas. Jadi, intervalnya adalah sebesar:

$$
\mathrm{I}=\frac{4-1}{4}=0,75
$$

Dengan demikian, dapat diketahui interpretasi jawaban responden mengenai kualitas pelayanan administrasi kependudukan sebagai berikut:

a) Nilai kualifikasi $3,26-4,00=$ sangat baik;

b) Nilai kualifikasi $2,51-3,25=$ baik;

c) Nilai kualifikasi $1,76-2,50=$ kurang baik; dan

d) Nilai kualifikasi $1,00-1,75=$ tidak baik

Sedangkan untuk mengetahui tingkat pencapaian dari SMM ISO 9001:2008, maka penulis menggunakan rumus Sugiyono (2006:95) sebagai berikut:

$$
\begin{aligned}
& \% \text { Skor } \\
& \begin{array}{l}
\text { Pencapaian } \\
\text { Skor Hasil } \\
\text { Penelitian) }
\end{array}
\end{aligned}=\frac{\begin{array}{c}
\text { Jumlah skor } \\
\text { jawaban hasil }
\end{array}}{\text { Skor jawaban ideal }} \times 100 \%
$$

Jawaban responden pada skala likert terdiri atas 4 alternatif jawaban, yaitu 4 sampai 1 . Skor jawaban tersebut dipersentasikan melalui rentang 25\%-100\% yang menunjukkan skor maksimum dan minimum. Skor maksimum diperoleh apabila seluruh responden memberikan jawaban 4 sedang skor minimum diperoleh apabila seluruh responden memberikan jawaban 1 atau dapat dilihat melaui perhitungan berikut:

$$
\begin{aligned}
& \begin{array}{l}
\% \text { Skor } \\
\text { Maksimum }
\end{array}=\frac{4 \times 150}{600} \times 100 \%=100 \% \\
& \begin{array}{l}
\% \text { Skor } \\
\text { Minimum }
\end{array}=\frac{1 \times 150}{600} \times 100 \%=25 \%
\end{aligned}
$$

Kemudian untuk menentukan jarak antar kelas interval, diperoleh dengan rumus:

$$
\begin{aligned}
& \text { Jarak } \\
& \text { Interval }
\end{aligned}=\frac{\begin{array}{c}
\text { Skor maksimum - } \\
\text { skor minimum }
\end{array}}{\text { Jarak kelas interval }} \times 100 \%
$$

Berdasarkan rentang kelas interval di atas, maka ditentukan nilai kualifikasi tingkat pencapaian sebagai berikut: a) Nilai kualifikasi $81,26 \%-100 \%=$ sangat efektif; b) Nilai kualifikasi $62,51 \%-81,25 \%$ = efektif; c) Nilai kualifikasi 43,76\% - 62,50\%= kurang efektif; d) Nilai kualifikasi $25 \%-43,75 \%=$ tidak efektif.

\section{HASIL DAN PEMBAHASAN}

\section{Deskripsi Daerah Penelitian}

Wilayah Pemerintahan Daerah Kota Blitar secara administratif terbagi dalam 3 (tiga) Kecamatan yaitu Kecamatan Kepanjenkidul, Sukorejo dan Sananwetan, masing-masing kecamatan terdiri dari 7 (tujuh) kelurahan. Dari tiga kecamatan tersebut terdapat 21 kelurahan dengan jumlah sebanyak 186 RW dan $634 \quad$ RT (http://blitarkota.bps.go.id/index.php/) Kecamatan terluas adalah Kecamatan Sananwetan dengan luas $12,15 \mathrm{~km}^{2}$ kemudian Kecamatan Kepanjenkidul 10,50 $\mathrm{km}^{2}$ dan Kecamatan Sukorejo 9,93 km². Dari 21 kelurahan yang ada, kelurahan terluas adalah Kelurahan Sentul yang terletak di Kecamatan Kepanjenkidul yaitu 2,68 km². Sementara Kelurahan dengan luas terkecil adalah Kelurahan Turi, Kecamatan Sukorejo yaitu 0,51 km².

Berdasarkan hasil registrasi penduduk tahun 2009, jumlah penduduk Kota Blitar pada tahun 2010 meningkat sebesar 0,79 persen dibandingkan dengan tahun sebelumnya. pada tahun 2009 jumlah penduduknya sebesar 139.471 jiwa, maka pada tahun 2010 sebanyak 140.574 jiwa. Sedangkan rasio jenis kelaminnya dibawah 100 yang artinya jumlah penduduk perempuan masih lebih banyak dibandingkan dengan jumlah penduduk laki-laki. Kecamatan dengan jumlah penduduk terbesar adalah Kecamatan Sananwetan dengan jumlah penduduk sebesar 52.742 jiwa, diikuti Kecamatan Sukorejo sebesar 47.750 jiwa, dan yang terkecil adalah penduduk kecamatan Kepanjenkidul sebesar 40.082 jiwa. Sedangkan tingkat kepadatan penduduk Kota Blitar pada tahun 2010 mencapai $4.315 \mathrm{jiwa} / \mathrm{km} 2$ atau sekitar 4 orang/m2. Sementara kecamatan terpadat adalah Kecamatan Sukorejo yaitu 4.811 jiwa/km2 yang kemudian diikuti oleh Kecamatan Sananwetan yaitu 4.340 jiwa/km2 dan Kecamatan Kepanjenkidul yaitu 3.816 jiwa/km2. Selanjutnya kelurahan dengan penduduk terpadat adalah Kelurahan Sukorejo dengan tingkat kepadatan mencapai 9.622 jiwa/km2, diikuti dengan Kelurahan Kepanjenlor (9.410 jiwa/ km2) dan Kelurahan Kepanjenkidul (9.258 jiwa/km2) (http://blitarkota. bps.go.id/index.php/).

Kota Blitar adalah Kota Kecil dengan jumlah Pegawai Negeri Sipil yang berada di lingkungan Pemerintah Kota Blitar sebanyak 4.366 orang, dengan jumlah PNS pria sebanyak 2.136 orang, dan wanita sebanyak 2.230 orang. Dari junmlah PNS sebanyak itu, mereka tersebar di berbagai satuan kerja (Satker), unit kerja dengan jumlah PNS terbanyak adalah Dinas Pendidikan dan Kebudayaan, sebanyak 2.302 oang yang termasuk di dalamnya guru, kemudian terbanyak 
Tabel 1. Rekapitulasi Skor Sub Variabel Bukti Langsung (Tangibles)

\begin{tabular}{|c|c|c|c|c|c|}
\hline No & Aspek & $\begin{array}{c}\text { Nilai } \\
\text { Kualifikasi }\end{array}$ & Kriteria & $\begin{array}{c}\text { Tingkat } \\
\text { Pencapaian } \\
(\%)\end{array}$ & Kriteria \\
\hline \multirow[t]{4}{*}{1} & Kelengkapan & & & & \\
\hline & $\begin{array}{l}\text { Sarana } \quad \& \\
\text { prasarana: }\end{array}$ & & & & \\
\hline & $\begin{array}{l}\text { a. Sarana dan } \\
\text { Prasarana }\end{array}$ & 3,20 & baik & 80,00 & efektif \\
\hline & $\begin{array}{l}\text { b. Kondisi } \\
\text { peralatan }\end{array}$ & 3,20 & baik & 85,33 & $\begin{array}{l}\text { Sangat } \\
\text { efektif }\end{array}$ \\
\hline \multirow[t]{5}{*}{2} & Kenyamanan: & & & & \\
\hline & $\begin{array}{l}\text { a. Kondisi } \\
\text { kebersihan }\end{array}$ & 3,26 & $\begin{array}{l}\text { Sangat } \\
\text { baik }\end{array}$ & 82,33 & $\begin{array}{l}\text { Sangat } \\
\text { efektif }\end{array}$ \\
\hline & $\begin{array}{ll}\text { b. } & \text { Kondisi } \\
\text { ketertiban }\end{array}$ & 3,32 & $\begin{array}{l}\text { Sangat } \\
\text { baik }\end{array}$ & 83,00 & $\begin{array}{l}\text { Sangat } \\
\text { efektif }\end{array}$ \\
\hline & $\begin{array}{ll}\text { c. Kondisi } \\
\text { keteraturan }\end{array}$ & 3,34 & $\begin{array}{l}\text { Sangat } \\
\text { baik }\end{array}$ & 85,83 & $\begin{array}{l}\text { Sangat } \\
\text { efektif }\end{array}$ \\
\hline & $\begin{array}{l}\text { d. Kenyaman } \\
\text { suasana }\end{array}$ & 3,06 & baik & 76,66 & efektif \\
\hline \multirow[t]{2}{*}{3} & $\begin{array}{l}\text { Tingkat } \\
\text { Kemudahan } \\
\text { akses }\end{array}$ & 3,45 & $\begin{array}{l}\text { Sangat } \\
\text { baik }\end{array}$ & 86,33 & $\begin{array}{l}\text { Sangat } \\
\text { efektif }\end{array}$ \\
\hline & Jumlah rata-rata & 3,26 & $\begin{array}{l}\text { Sangat } \\
\text { baik }\end{array}$ & 82,78 & $\begin{array}{l}\text { Sangat } \\
\text { efektif }\end{array}$ \\
\hline
\end{tabular}

berikutnya adalah pegawai yang berada di RSUD Mardi Waluyo sebanyak 498 orang. Jika dibedakan berdasarkan golongan, jumlah PNS dengan Golongan I sebanyak 180 orang (4,12 persen), golongan II sebanyak 1.202 orang (27,53 persen), golongan III sebanyak 1.740 orang ( 39,85 persen) dan golongan IV sebanyak 1.244 orang (28,49 persen). Jika dilihat dari pendidikannya PNS yang berependidikan SLTA sebanyak 1.307 orang $(29,93$ persen), berpendidikan D1, D2, D3, D4 sebanyak 829 orang (18,99 persen). Kemudian PNS dengan pendidikan S1 orang $(46,84$ persen), dan mereka yang berpendidikan S2 sebanyak 185 orang $(4,24$ persen) (http://blitarkota.bps. go.id/index.php/).

Pemerintahan Kota Blitar tidak lepas dari peran DPRD hasil Pemilu 2009, anggota DPRD Kota Blitar sebanyak 25 orang yang tergabung ke dalam 3 Komisi - Komisi I terdiri dari 7 anggota membidangi Pemerintahan, sedangkan Komisi II terdiri dari 8 anggota membidangi Perekonomian dan Keuangan. Kemudian Komisi III terdiri dari 7 anggota membidangi Pembangunan. Anggota DPRD Kota Blitar didominasi oleh PDI-P dan Partai Demokrat yaitu masing-masing sebanyak 6 orang. Posisi kedua ditempati oleh PKB, Partai Golkar dan PPP yaitu masing-masing 3 orang. Berikutnya dari Partai Hanura 2 orang, PKS dan PKNU masing-masing 1 orang. Sedangkan anggota DPRD perempuan hanya ada 4 orang, berasal dari Partai Demokrat 2 orang dan dari PKB dan PKS masing-masing 1 orang (http://blitarkota.bps. go.id/index.php/).

Secara geografis Kota Blitar hanya berbatasan langsung dengan Kabupaten Blitar, tidak berbatasan dengan daerah lainnya seperti Kabupaten Tulunagung, Kediri maupun Kabupaten Malang karena posisi Kota Blitar berada ditengah-tengah Kabupaten Blitar. Adapun kecamatan di Kabupaten Blitar yang berbatasan dengan wilayah Kota Blitar adalah sebelah utara berbatasan dengan Kecamatan Nglegok, sebelah timur berbatasan dengan Kecamatan Garum, di sebelah selatan berbatasan dengan Kecamatan Kanigoro, dan sebelah Barat berbatasan dengan Kecamatan Sanankulon (http://blitarkota.bps. go.id/index.php/). Sedangkan wilayah Kota Blitar dilihat dari topografi masih termasuk dataran rendah, dengan luas wilayah hanya $32,58 \mathrm{~km}^{2}$, berada diketinggian dari permukaan air laut rata-rata sekitar $156 \mathrm{~m}$. Ketinggian di bagian utara sekitar $245 \mathrm{~m}$ dengan tingkat kemiringan $2^{\circ}$ sampai $15^{\circ}$, bagian tengah $175 \mathrm{~m}$ dan bagian Selatan $140 \mathrm{~m}$ dari permukaan air laut dengan tingkat kemiringan $0^{\circ}$ sampai $2^{\circ}$ (http://blitarkota.bps. go.id/index.php/).

\section{Analisis Efektivitas SMM ISO 9001:2008 dalam Mewujudkan Pelayanan Berkualitas Tangibel (Bukti Langsung)}

Indikator sub variabel bukti langsung ada tiga, yaitu kelengkapan sarana dan prasarana, kenyamanan, serta kemudahan askes. Untuk menganalisis sub variabel ini secara keseluruhan, dikemukakan hasil pendapat responden yang tersebar di tiga kecamatan, yaitu Sananwetan, Sukorejo dan Kecamatan Kepanjenkidul.

Berdasarkan tabel tentang rekapitulasi skor jawaban responden untuk variabel tangibles, dapat dijelaskan bahwa secara umum masyarakat 
Tabel 2.Rekapitulasi Skor Sub Variabel Kehandalan (Reliability)

\begin{tabular}{|c|c|c|c|c|c|}
\hline No & Aspek & $\begin{array}{c}\text { Nilai } \\
\text { Kualifikasi }\end{array}$ & Kriteria & $\begin{array}{c}\text { Tingkat } \\
\text { Pencapaian } \\
(\%)\end{array}$ & Kriteria \\
\hline 1 & Kesederhanaan & 3,60 & $\begin{array}{c}\text { Sangat } \\
\text { baik }\end{array}$ & 90,16 & $\begin{array}{l}\text { Sangat } \\
\text { efektif }\end{array}$ \\
\hline \multirow[t]{8}{*}{2} & Kepastian dan kejelasan: & & & & \\
\hline & $\begin{array}{l}\text { Target \& waktu } \\
\text { penyelesaian }\end{array}$ & 3,06 & baik & 76,50 & efektif \\
\hline & b. Ada tidaknya pungli & 3,46 & $\begin{array}{c}\text { Sangat } \\
\text { baik }\end{array}$ & 86,66 & $\begin{array}{l}\text { Sangat } \\
\text { efektif }\end{array}$ \\
\hline & $\begin{array}{l}\text { c. Pemberian tanda bukti } \\
\text { pembayaran }\end{array}$ & 1,79 & $\begin{array}{c}\text { Kurang } \\
\text { baik }\end{array}$ & 44,83 & $\begin{array}{l}\text { Kurang } \\
\text { efektif }\end{array}$ \\
\hline & $\begin{array}{l}\text { d. Waktu pelayanan } \\
\text { sesuai tidaknya dgn } \\
\text { ketentuan }\end{array}$ & 3,10 & baik & 77,66 & efektif \\
\hline & e. Standar biaya & 3,69 & $\begin{array}{l}\text { Sangat } \\
\text { baik }\end{array}$ & 92,33 & $\begin{array}{l}\text { Sangat } \\
\text { efektif }\end{array}$ \\
\hline & $\begin{array}{ll}\text { f. } & \text { Pemahaman } \\
\text { masyarakat ttg } \\
\text { persyaratan pembuatan } \\
\text { KTP/KK }\end{array}$ & 3,16 & baik & 79,16 & efektif \\
\hline & $\begin{array}{l}\text { g. Kejelasan identitas, } \\
\text { jabatan, kewenangan } \\
\text { petugas }\end{array}$ & 2,76 & baik & 69,00 & efektif \\
\hline 3 & Kedisiplinan petugas & 3,36 & $\begin{array}{c}\text { Sangat } \\
\text { baik }\end{array}$ & 84,50 & $\begin{array}{l}\text { Sangat } \\
\text { efektif }\end{array}$ \\
\hline 4 & Transparansi & 3,26 & $\begin{array}{l}\text { Sangat } \\
\text { baik }\end{array}$ & 81,50 & $\begin{array}{l}\text { Sangat } \\
\text { efektif }\end{array}$ \\
\hline \multirow[t]{2}{*}{5} & Akurasi pelayanan & 3,14 & Baik & 78,66 & Efektif \\
\hline & Jumlah rata & 3,12 & Baik & 78,26 & Efektif \\
\hline
\end{tabular}

Sumber: data primer diolah

berpendapat kelengkapan sarana dan prasarana yang dimiliki oleh pelayanan administrasi kependudukan baik di tingkat kecamatan maupun di tingkat Dinas Kependudukan dan Catatan Sipil kondisinya baik dengan nilai kualifikasi 3,20 dan tingkat pencapaian 80,00 dengan kriterian efektif. Masyarakat memandang kondisi baik terhadap peralatan yang dipunyai oleh pelayanan publik yang mengurus pelayan Kependudukan baik di tingkat kecamatan maupun di tingkat Satker (satuan Kerja) di Dinas Kependudukan dan Catatan Sipil dengan nilai kualifikasi 3,20 dengan tinmgkat pencapaian 85,33 dalam criteria sangat efektif.

Demikian pula dengan kondisi aspek kenyamanan pelayanannya terutama kondisi kebersihan kantor dipandang oleh masyarakat sangat baik (bersih), dengan kriteria 3,26, dengan tingkat pencapaian 82,33 sangat efektif, tidak itu saja bila dilihat dari sisi ketertiban adminsitrasi maupun pegawainya dipandang oleh masyarakat sangat baik, dengan kriteria 3,32 dan tingkat pencapaina sebesar 83,00 sangat efektif. Disisi tingkat keteraturan administrasi pelayanan dipandang oleh masyarakat sangat baik dengan kriteria 3,34 dan tingkat pencapaian 85,83 kualifikasi sangat efektif. Kemudian aspek kenyaman terutama dari sisi kenyamanan suasana dipandang oleh masyarakat penerima layanan baik, artinya tempat pelayanan baik ditingkat kecamatan maupun ditingkat dinas suasana menyenangkan, seprti adanya ruang tunggu, ruang parkir yang memadahi, papan informasi yang cukup dan sebagainya. Hal dapat dilihat hasil nilai kualifikasi seebsar 3,06 dengan kriterian baik dan tingkat pencapaian sebesar 76,66 dengan kriteria efektif.

Pelayanan administrasi kependudukan bila dilihat dari aspek kemudahan akses seperti bagaimana mengakses informasi tentang pelayanan maupun dari sisi posisi strategis kantor dipandang oleh masyarakat penerima pelayanan sangat baik dengan nilai kualifikasi 3,45 dan tingkat pencapaian sebesar 86,33 dalam kualiofikasi sangat efektif.

Kondisi pelayanan dilihat dari variabel bukti langsung (tangibles) baik dari sisi aspek kelengkapan sarana dan sarana, aspek kenyaman maupun tingkat kemudahan akases nilai kualifikasi rata-rata 3,26 dalam kriteria sangat baik, sedangkan tingkat pencapaian rata-rata 82,78 dalam kriteria sangat efektif.

\section{Kehandalan}

Pelayanan pembuatan dokumen administrasi kependudukan dapat dilihat dari variable kehandalan (reliability) yang berkaitan dengan unsur-unsur pelayanan publik berupa prosedur dan persyaratan pelayanan, waktu penyelesaian pelayanan, biaya pelayanan, unit kerja/pejabat yang berwenang dan bertanggungjawab dalam penyelenggaraan dan penyelesaian pelayanan, jadwal pelayanan, serta 
Tabel 3. Rekapitulasi Skor Sub Variabel Daya Tanggap

\begin{tabular}{|llcccc|}
\hline No & & $\begin{array}{c}\text { Nilai } \\
\text { Kualifikasi }\end{array}$ & Kriteria & $\begin{array}{c}\text { Tingkat } \\
\text { Pencapaian (\%) }\end{array}$ & Kriteria \\
\hline 1 & $\begin{array}{l}\text { Tanggung jawab } \\
\text { Daya tanggap terhadap } \\
\text { pengaduan tentang } \\
\text { pelayanan pembuatan }\end{array}$ & 3,07 & Baik & 76,83 & Efektif \\
& $\begin{array}{l}\text { KTP dan KK } \\
\text { Daya tanggap dalam } \\
\text { menerima kritik, saran }\end{array}$ & 3,24 & Baik & 81,16 & Efektif \\
& $\begin{array}{l}\text { Akuntabilitas } \\
\text { Jumlah rata-rata }\end{array}$ & 3,16 & Baik & 79,00 & Efektif \\
& 3,15 & Baik & 78,99 & Efektif \\
\hline
\end{tabular}

Sumber: data primer diola

produk pelayanan. Kemudian dari sini diukur melalui beberapa indikator yaitu kesederhanaan, kepastian dan kejelasan, kedisiplinan, transparansi, dan akurasi. Untuk melihat kehandalan pelayanan pembuatan KTP/KK dapat dilihat pada rekapitulasi skor sub variabel kehandalan (reliability) pada tabel di bawah ini

Berdasarkan tabel tentang rekapitulasi skor jawaban responden untuk sub variable kehandalan, dapat dijelaskan bahwa secara umum masyarakat berpendapat kehandalan (reliability) bila dilihat dari aspek kesederahanaan dipandang oleh masyarakat sebagai penerima pelayanan sangat baik dengan nilai kualifikasi sebesar 3,60 dengan tingkat pencapaian sebesar 90,16 dalam kriteria sangat efektif. Kemudian dari sisi aspek kepastian dan kejelasan yang meliputi target dan waktu penyelesaian dipandang oleh masyarakat sebagai pengguna layanan baik dengan nilai kualifikasi 3,06 dengan kriteria baik dan tingkat pencapain sebesar 76,50 kriteria efektif. Kemudian ada tidaknya pungli tentang pelayanan pembuatan administrasi kependudukan di Kota Blitar dipandang oleh penemrima layanan sangat baik dengan nilai kualifikasi sebesar 3,46 dengan tingkat pencapaian sebesar 86,66 sangat efektif, namun demikian bukan berarti dalam pelayanan tidak ada pungli walaupun masih ada pungli relatif kecil sekali. Aspek kepastian dan kejelasan dari sisi pemberian tanda bukti pembayaran dinilai oleh masyarakat masih kurang hal ini terbukti nilai kualifikasi hanya sebesar 1,79 dan tingkat pencapaian sebesar 44,83 dengan kriteria kurang efektif.

Kemudian dari sisi waktu pelayanan sesuai tidaknya dengan ketentuan yang berlaku, dipandang oleh masyarakat waktu pelayanan sesuai dengan ketentuan yang berlaku hal ini dapat dibuktikan dengan nilai kualifikasi sebesar 3,10 dengan kriteria baik, dan tingkat pencapaian sebesar 77,66 kriteria efektif. Tentang standar biaya dinilai oleh masyarakat sangat baik dengan nilai kualifikasi sebesar 3,69 dan tingkat pencapaian sebesar 92,33 krioteria sangat efektif. Masyarakat penerima pelayanan maham persoalan tentang persyarakatan pembuatan KTP/KK, hal ini terbukti nilai kualifikasi 3,16 kriteria baik dengan tingkat pencapaian sebesar 79,16 kriteria efektif. Bagaimana dengan persoalan kejelasan identitas, jabatan, kewenangan petugas, dipandang oleh masyarakat penerima pelayanan baik, artinya identitas, jabatan dan kewenangan masing-masing petugas sudah jelas, hal ini terbukti nilai kualifikasi sebesar 2,76 dengan kriteria baik dan tingkat pencapaian sebesar 69,00 kriteria efektif.

Selanjutnya pelayanan pembuatan KTP dan KK oleh Dinas Kependudukan dan Catatan Sipil Kota Blitar dilihat dari aspek kedisplinan petugas dipandang oleh masyarakat penerima layanan sangat baik, kondisi seperti ini dapat dilihat pada nilai kualifikasi sebesar 3,36 kriteria sangat baik dan tingkat pencapaian sebesar 84,50 dengan kriteria sangat efektif. Kemudian dari aspek transparansi petugas dalam memberikan pelayanan dipandang oleh masyarakat sangat transparan (baik), kondisi ini dapat dilihat nilai kualifikasi sebesar 3,26 kriteria sangat baik dan tingkat pencapaian sebesar 81,50 sangat efektif. Bagaimana dengan akurasi petugas dalam memberikan pelayanan? Petugas dalam memberikan pelayanan sedikit sekali dalam melakukan kesalahan, walaupun ada kesalahan relatif kecil sekali kesalahan tersebut. Kondisi akurasi ini dapat dikonfirmasikan dengan nilai kualifikasi akurasi pelayanan sebesar 3,14 dalam kriteria baik dan tingkat pencapaian sebesar 78,66 dengan kriteria efektif.

Kualitas pelayanan pembuatan KTP dan KK bila dilihat dari sisi variabel kehandalan (reliability) dari aspek kesederhanaan , kepastian dan kejelasan, kedisiplinan petugas dan transparansi serta akurasi pelayanan dipandang oleh masyarakat sudah baik. Kondisi ini dapat dilihat pada nilai jumlah rata-rata nilai kualifikasi sebesar 3,12 dengan kriteria baik dan tingkat pencapaian sebesar 78,26 dalam kriteria efektif.

\section{Daya Tanggap (Responsiveness)}

Kualitas pelayanan administrasi pembuatan KTP dan KK dapat dilihat dari variabel daya tanggap. Dari aspek daya tanggap terhadap pengaduan tentang pelayanan pembuatan KTP dan KK. Dilihat dari aspek ini masyarakat memandang bahwa petugas dalam 
Tabel 4. Rekapitulasi Skor Sub Variabel Jaminan

\begin{tabular}{|c|c|c|c|c|c|}
\hline No & Aspek & $\begin{array}{c}\text { Nilai } \\
\text { Kualifikasi }\end{array}$ & Kriteria & $\begin{array}{c}\text { Tingkat } \\
\text { Pencapaian }(\%)\end{array}$ & Kriteria \\
\hline 1 & Competence & & & & \\
\hline a & $\begin{array}{l}\text { Keahlian aparat pemberi } \\
\text { layanan sesuai tidaknya } \\
\text { dengan bidang tugasnya }\end{array}$ & 3,03 & Baik & 75,83 & Efektif \\
\hline $\mathrm{b}$ & $\begin{array}{l}\text { Aparat telah memiliki } \\
\text { tidaknya ketrampilan yang } \\
\text { baik memberikan layanan }\end{array}$ & 3,08 & Baik & 75,83 & Efektif \\
\hline 2 & Courtecy & 3,21 & Baik & 80,33 & Efektif \\
\hline 3 & Credibility & & & & \\
\hline a & $\begin{array}{l}\text { Tingkat kejujuran dari aparat } \\
\text { pelayanan pembuatan } \\
\text { KTP/KK }\end{array}$ & 3,10 & Baik & 77,50 & Efektif \\
\hline $\mathrm{b}$ & $\begin{array}{l}\text { Perasaan selama } \\
\text { mendapatkan pelayanan } \\
\text { pembuatan KTP/KK } \\
\text { misalnya karena tidak } \\
\text { dipersulit dsb }\end{array}$ & 3,25 & Baik & 81,33 & Efektif \\
\hline \multirow[t]{2}{*}{4} & Security & 3,26 & Sangat baik & 81,66 & $\begin{array}{l}\text { Sangat } \\
\text { efektif }\end{array}$ \\
\hline & Jumlah rata & 3,15 & Baik & 78,74 & Efektif \\
\hline
\end{tabular}

memberikan pelayanan mempunyai daya tanggap yang baik terhadap berbagai pengaduan dari masyarakat sebagai pengguna layanan, kondisi daya tanggap dalam persoalan pengaduan ini dapat dilihat nilai kualifikasi sebesar 3,07 dalam kriteria baik dan tingkat pencapaian sebesar 76,83 kriteria efektif.

Kemudian daya tanggap dari sisi dalam menerima kritik, saran masyarakat melihat bahwa para petugas ataupun aparat dalam memberikan pelayanan pembuatan KTP dan KTT bersikap baik dalam menerima kritik maupun saran dari pengguna pelayanan. Sikap petugas dalam menerima kritik dan saran cukup terbuka, hal ini dapat dikonfirmasikan dengan nilai kualifikasi sebesar 3,24 dengan kriteria baik dan tingkat pencapaian sebesar 79,00 dalam kriteria efektif. Selanjutnya daya tanggap bila dilihat dari aspek akuntabilitas yang dapat berupa mutu pelayanan tentang persyaratan pembuatabn KTP dan KK dipandang oleh masyarakat Kota Blitar sebagai pengguna layanan baik akungtabiltasnya. Kondisi ini dapat dilihat nilai kualifikasi daya tanggap dari aspek akuntabilitas mendapatkan nilai kualifikasi sebesar 3,16 dalam kriteria baik dan tingkat pencapaian sebesar 79,00 dengan kriteria efekti.f.

Kondisi pelayanan dalam pembuatan KTP dan KK di Kota Blitar dilihat dari daya tanggap petugas pelayanan nilai kualifikasi jumlah rata-rata sebesar 3,15 dengan kriteria baik dan tingkat pencapaian sebesar 78,99 dengan criteria efektif

\section{Jaminan (Assurance)}

Kualitas petugas dalam memberikan pelayanan dapat dilihnat dari variabel jaminan (assurance) diukur melalui empat indikator, yaitu competence, courtecy, credibility, dan security. Untuk menganalisis variabel jaminan (assurance) secara keseluruhan, dapat dilihat darti pendapat masyarakat yang menjadi respponden terhadap masing-masing indikator. Oleh karena itu untuk melihat bagaimana kondisi jaminan dapat dilihat pada rekapitulasi skor sub variabel jaminan pada Tabel 4.

Kualitas pelayanan dilihat dari variabel jamin (assurance) dari aspek competence terutama indikator keahlian aparat pemberi layanan sesuai tidaknya dengan bidang tugasnya. Pada indikator keahlian aparat pemberi layanan dipandang oleh masyarakat penerima pelayanan pembuatan KTP dan KK di Kota Blitar petugasnya kompetensinya baik, artinya petugas pemberi layanan sudah sesuai dengan bidang tugasnya. Kondisi kompetnsi dari sisi keahliannya dapat dilihat dari nilai kualifikasi sebesar 3,03 dengan kriteria baik dan tingkat pencapaian sebesar 75,83 kriteria efektif. Kemudian aspek kompetensi dari sisi aparat memiliki tidaknya ketrampilan yang baik dalam memberikan pelayanan nilai kualikasi sebesar 3,08 dalam kriteria baik tingkat ketrampilannya dan tingkat pencapaian sebesar 75,83 dengan kriteria efektif.

Selanjutnya kualitas petugas pelayanan pembuatyan KTP dan KK dapat dilihat dari aspek courtecy dan aspek credibility. Pelayanan dilihat dari aspek courtecy dipandang oleh masyarakat penerima pelayanan telah baik, hal ini dapat dilihat nilai kualifikasi sebesar 3,21 dengan kriteria baik dan tingkat pencapaian sebesar 80,33 dengan kriteria efektif. Kemudian pelayanan dilihat dari aspek credilility terutama dari sisi tingkat kejujuran dari 
aparat pelayanan, dari sisi ini dipandang oleh masyarakat petugas telah mempunyai tingkat kejujuran yang baik, kondisi ini dapat dilihat dari nilai kualifikasi sebesar 3,10 dengan kriteria baik dan tingkat pencapaian sebesar 77,50 kriteria efektif. Kemudian kridibilitas petugas pelayanan dilihat dari indikator perasaan masyarakat selama mendapatkan pelayanan pembuatan KTP dan KK merasakan tidak dipersulit oleh petugas, kondisi ini dapat dilihat dari nilai kualifikasi sebesar 3,25 dengan kriteria baik dan tingkat pencapaian sebesar 81,33 kriteria efektif. Kompetensi petugas pelayanan dapat dilihat dari aspek security, masyarakat sebagai penerima layanan berpandangan bahwa dari sisi security di lingkungan kantor pelayanan pembuatan KTP dan KK baik pelayanan di tingkat kecamatan maupun di tingkat Dinas Kependudukan dan catatan Sipil Koat Blitar sanat baik, kondisi ini dapat dilihat nilai kualifikasi sebesar 3,26 dengan kriteria sangat baik dan tingkat pencapaian sebesar 81,66 kriteria efektif.

Kualitas pelayanan pembuatan KTP dan KK untuik variabel jaminan, dapat dijelaskan bahwa secara umum masyarakat berpendapat kualitas pelayanan dari sisi jaminan dari sisi aspek competence, courtecy, credibility, dan security dalam pelayanan pembuatan KTP dan KK di Kota Blitar mendapatkan jumlah rata-rata nilai kualifikasi sebesar 3,15 dalam kriteria baik dengan tingkat pencapaian rata-rata 78,74 dalam kriteria efektif.

\section{Empati (Empathy)}

Kualitas pelayanan pembuatan KTP dan KK di Kota Blitar dapat dilihat dari variabel empati. Empati di sini adalah bagaimana cara petugas pelayanan dalam melayani masyarakat dengan penuh perhatian, kemudahan dalam melakukan komunikasi yang baik dan memahami kebutuhan masyarakat sehingga tujuan berkomunikasi untuk memberikan informasi dapat tercapai. Indikator empati ada dua, yaitu communication dan understanding the customer.

Kualitas pelayanan pembuatan KTP dan KK di Kota Blitar dilihat dari aspek communication. Masyarakat pengguna layanan melihat pelayanan dari aspek komunikasi petugas pelayanan baik, artinya mereka mau mendengarkan, berbicara sopan, dapat mudah dimengerti, baik dan ramah. Kondisi ini dapat dilihat nilai kualifikasi aspek komunikasi sebesar 3,14 dengan kriteria baik dan tingkat pencapaian sebesar 78,50 dengan kriteria baik.

Kualitas pelayanan pembuatn KTP dan KK dari aspek understanding the costumer terutama dari indikator apakah masih membeda-bedakan suku, ras, agama, golongan, jenis kelamin, status ekonomi. Dari indikator ini masyarakat penerima layanan berpendapat selama ini petugas tidak membedabedakan suku, ras, agama, golongan, jenis kelamin dan status ekonomi mereka. Kondisi ini dapat dilihat nilai kualifikasi sebesar 3,24 dengan kriteria baik dan tingkat pencapaian sebesar 81,16 kriteria efektif. Demikian juga masyarakat merata atau tidaknya jangkauan pelayanan yang diberikan aparat keseluruh lapisan masyarakat, masyarakat sebagai penerima pelayanan memandang pelayanan telah merata di semua lapisan masyarakat. Kondisi ini dapat dilihat dari nilai kualifikasi sebesar 3,14 dengan kriteria baik dan tingkat pencapaian sebesar 78,50 kriteria efektif.

Kemudian kualitas pelayanan dapat pula dilihat dari indikator aparat pelayanan memenuhi atau tidaknya hak dan kewajiban masing-masing orang yang mengurus KTP/KK. Petugas dalam memberikan pelayanan selama ini dipandang telah memnuhi hak dan kewajiban masing-masing orang dengan baik. Kondisi ini dapat dilihat dari nilai kualifikasi sebesar 3,06 dengan kriteria baikdan tingkat pencapaian sebesar 76,60 kriteria efektif. Selain itu kualitas pelayanan petugas dapat dilihat dari sikap aparat dalam menerima keluhan, pengaduan, saran, dan kebutuhan pelanggan, dalam hal ini petugas dinilai oleh masyarakat telah bersikap baik, dalam arti mau m,enerima keluhan, pengaduan, saran dan mau melihatb kebutuhan pelanggan. Kondisi ini dapat dilihat nilai kualifikasi sebear 3,46 dengan kriteria sangat baik dan tingkat pencapaian sebesar 86,66 kriteria sangat efektif.

Kualitas pelayanan pembuatan KTP dan KK di Kota Blitar dilihat dari variabel empati yang terdiri dari aspek communication dan understanding the costumer secara umum dapat dikatakan jumlah ratarata nilai kualifikasi 3,21 dalam kriteria baik, dengan tingkat pencapaian rata-rata 80,18 dalam kriteria efektif.

\section{Hasil Analisis Efektivitas SMM ISO 9001:2008}

Berdasarkan hasil rekapitulasi mengenai pendapat masyarakat tentang kualitas pelayanan administrasi kependudukan pembuatan KTP dan KK yang menggabungkan 5 (lima) variabel. Sub variabel ini merupakan pengembangan dari berbagai teori kualitas pelayanan menurut Parasuraman yang dideskripsikan guna untuk mengetahui tingkat pencapaian dari SMM ISO 9001:2008 di Kota Blitar. Dari variabel bukti langsung (tangibles) mendapatkan tingkat pencapaian yang paling tinggi diantara variabel yang lain, yaitu tingkat pencapiannya sebesar $82,78 \%$ dalam kriteria sangat efektif. Sedangkan variabel lainnya mendapatkan kriteria pencapaian efektif, baik itu variabel kehandalan (reliability), daya tanggap (responsiveness), jaminan (assurance) maupun variabel empati.

Sesuai dengan rekapitulasi hasil analisis efektivitas SMM ISO 9001:2008 di Kota Blitar nampak efektif dengan jumlah tingkat pencapaian rata-rata 79,98, artinya SMM ISO 9001:2008 mampu mendorong terhadap pelayanan administrasi pembuatan KTP dan KK yang berkualitas.

\section{Faktor yang Mempengaruhi Efektivitas SMM ISO 9001:2008}

Sistem manajemen mutu di Kota Blitar dalam memberikan pelayanan pembuatan KKTP dan KK 
Tabel 5. Rekapitulasi Skor Sub Variabel Empati

\begin{tabular}{|c|c|c|c|c|c|}
\hline \multicolumn{2}{|l|}{ No } & $\begin{array}{c}\text { Nilai } \\
\text { Kualifikasi }\end{array}$ & Kriteria & $\begin{array}{c}\text { Tingkat } \\
\text { Pencapaian }(\%)\end{array}$ & Kriteria \\
\hline 1 & Communication & 3,14 & Baik & 78,50 & Efektif \\
\hline 2 & Understanding the costumer & & & & \\
\hline A & $\begin{array}{l}\text { Petugas dalam memberikan } \\
\text { prioritas pelayanan dalam } \\
\text { pembuatan KTP/KK, apakah } \\
\text { masih membeda-bedakan suku, } \\
\text { ras, agama, golongan, jenis } \\
\text { kelamin, status ekonomi }\end{array}$ & 3,24 & baik & 81,16 & Efektif \\
\hline B & $\begin{array}{l}\text { Merata atau tidaknya jangkauan } \\
\text { pelayanan pembuatan KTP/KK }\end{array}$ & 3,14 & Baik & 78,50 & Efektif \\
\hline $\mathrm{c}$ & $\begin{array}{l}\text { Aparat pelayanan memenuhi atau } \\
\text { tidaknya hak dan kewajiban } \\
\text { masing-masing orang yang } \\
\text { mengurus KTP/KK }\end{array}$ & 3,06 & Baik & 76,60 & Efektif \\
\hline d & $\begin{array}{l}\text { Sikap aparat dalam menerima } \\
\text { keluhan, pengaduan, saran, dan } \\
\text { kebutuhan pelanggan. }\end{array}$ & 3,46 & $\begin{array}{c}\text { Sangat } \\
\text { baik }\end{array}$ & 86,66 & $\begin{array}{l}\text { Sangat } \\
\text { efektif }\end{array}$ \\
\hline & Jumlah rata & 3,21 & Baik & 80,18 & Efektif \\
\hline
\end{tabular}

Sumber: data primer diolah

Tabel 6.Rekapitulasi Hasil Analisis Efektivitas SMM ISO 9001:2008

\begin{tabular}{|c|c|c|c|c|c|}
\hline \multirow[t]{2}{*}{ No } & \multirow[t]{2}{*}{ variabel } & \multicolumn{4}{|c|}{ Frekuensi Alternatif jawaban } \\
\hline & & $\begin{array}{c}\text { Nilai } \\
\text { klualifikasi }\end{array}$ & $\begin{array}{c}\text { Kriteria } \\
\text { Kualifikasi }\end{array}$ & $\begin{array}{c}\text { Tingkat } \\
\text { pencapaian }\end{array}$ & $\begin{array}{c}\text { Kriteria } \\
\text { Pencapaian }\end{array}$ \\
\hline 1 & Tangibles (bukti langsung) & 3,26 & Sangat baik & 82,78 & Sangat efektif \\
\hline 2 & Kehandalan (Reliability) & 3,12 & Baik & 78,26 & Efektif \\
\hline 3 & Daya Tanggap (Responsiveness) & 3,15 & Baik & 78,99 & Efektif \\
\hline 4 & Jaminan (Assurance) & 3,15 & Baik & 78,74 & Efektif \\
\hline 5 & Empati (Empathy) & 3,21 & Baik & 80,18 & Efektif \\
\hline & Jumlah rata-rata & 3,18 & Baik & 79,98 & Efektif \\
\hline
\end{tabular}

Sumber: data primer diolah

dapat dikatakan sepenuhnya efektif. Namun demikian pelayanan pembuatan KTP dan KK belum mencapai hasil yang maksimal yaitu dalam kreteria sangat efktif sesuai SMM ISO 9001:2008. Berdasarkan wawancara dengan pihak responden secara kualitatif banyak faktor yang menghambat untuk mencapai pelayaan yang maksimal yaitu dengan kreteria pelayanan sangat efektif sesuai dengan SMM ISO 9001:2008 adalah sebagai berikut:

1. Adanya biaya tambahan di luar ketentuan.

Pemerintah Kota Blitar dalam memberikan pelayanan perlu menetapkan standar biaya pelayanan dengan jelas dan terperinci dan transparan. Oleh karena itu pengenai standar biaya pelayanan handaknya diinformasikan kepada masyarakat sebagai pengguna pelayanan. Kondisi ini masih dirasakan oleh sebagian masyarakat pengguna layanan pembuatan KTP/KK, walaupun besar biaya telah ditetapkan namun dirasakan oleh masyarakat masih saja ditingkat kelurahan untuk mengurus dokumen masih terjadi pungutan di luar ketentuan.

2. Pelayanan yang masih kurang ramah.

Kondisi ini masih dirasakan oleh masyarakat yang mengurus dokumen KTP dan KK, pelayanan pembuatan ada yang masih kurang ramah. Dari sisi human relationnya masih kurang, terutama dalam persoalan keramahan petugas.

3. Kurangnya transparansi aparat dalam memberikan informasi.

Semua informasi tentang pelayanan masyarakat harus dapat diketahui oleh publik sebagai pengguna layanan. Penyampaian informasi bisa dilakukan baik secara formal maupun informal. Secara formal dapat dilakukan melalui pemberitahuan kepada pemerintahan di bawahnya dengan surat edaran yang menyangkut perihal prosedur, persyaratan, waktu penyelesaian pelayanan, besarnya biaya, dan jadwal pelaksanaan pelayanan.

4. Kurangnya Ketrampilan \& Kedislinan Aparat. Rupanya pelayanan pembuatan KTP dan KK di Kota Blitar tingkat ketrampilan aparat perlu mendapat perhatian sebab hasil penelitian masih ada yang menyatakan bahwa aparat pelayanan tidak ahli dan tidak trampil. Selain persoalan ketrampilan petugas, juga persoalan kedisiplinan petugas perlu menjadi perhatian, sebab masih 
ada responden yang menyatakan bahwa petugas masih tidak disiplin.

5. Empati Aparat.

Hasil peneltian masih ada yang menyatakan bahwa bahasa ataupun komunikasi petugas masih tidak jelas dan masih sulit dipahami. Demikian juga mereka ada yang menyatakan bahwa untuk jangkauan pelayanan masih tidak merata, dan aparat tidak memenuhi hak dan kewajibannya. Selain itu masih ada pula mereka yang menyatakan aparat pelayanan tidak berusaha mendengarkan keluhan pelanggannya, sehingga mereka merasakan tidak puas dengan layanannya

6. Akurasi dan daya tanggap petugas pelayanan. Pada pelayanan publik akurasi pelayanan sangat diperlukan, hal ini menyangkut benar tidaknya dokumen yang harus diterimanya. Demikian juga persoalan daya tanggap menjadi hal yang tidak kalah pentingnya dengan problem yang lainnya. Hasil penelitian masih ada sebagian masyarakat pengguna layanan ada yang menyatakan layanan pembuatan KTP dan KK tidak sesuai dengan harapan, masih ada kesalahan. Demikian juga masih ada pula yang menyatakan bahwa petugas pelayanan masih kurang daya tanggapnya. Tidak itu saja sikap aparat masih tidak terbuka.

7. Kehandalan Petugas Pelayanan.

Persoalan kehandalan dalam pelayanan pembuatan KTP dan KK masih perlu mendapatkan perhatian yang serius dari pihak pemerintah Kota Blitar, terutama yang menyangkut kesederhanaan prosedur pelayanan, target waktu penyelesaian, tanda terima bukti pelayanan terutama bukti pembayaran. Mereka yang masih mempersoalkan prosedur pelayanan cukup banyak pula. Mereka yang menyatakan bahwa prosedur pelayanan tidak sederhana, demikian pula mereka banyak pula yang menyatakan tidak ada kepastian dan kejelasan mengenai target waktu penyelesaian, tidak selesai dengan target waktu yang ditentukan. Banyak pula yang menyatakan selalu tidak diberi tanda bukti pembayaran.

8. Tangibel \& Kenyaman.

Demikian juga persoalan kenyaman pelayanan perlu mendapatkan perhatian. Hal ini dapat dilihat pada hasil penelitian, mereka yang menyatakan bahwa sarana dan prasarana masih dirasakan masih kurang. Tidak itu saja persoalan kenyamman pelayanan dirasakan masih kurang baik, tidak bersih, kurang tertib. Kondisi kantor jika dilihat dari keraturan administrasi ada sebagian masyarakat memandang masih tidak teratur, kurang nyaman.

\section{SIMPULAN}

Sesuai dengan hasil analisis mengenai efektivitas SMM ISO 9001:2008 di Kota Blitar mengenai pendapat masyarakat sebagai penerima layanan administrasi kependudukan terutama KTP dan KK yang meliputi bukti langsung, kehandalan, daya tanggap aparat pelayanan, jaminan, dan empati diperoleh nilai kualifikasi rata-rata 3,18 dengan kriteria baik, sedangkan tingkat pencapaian rata-rata sebesar 79,98\% dengan kriteria pencapaian efektif. Sedangkan faktor yang mempengaruhi tidak maksimalnya untuk menuju pelayaan yang sangat efektivitas sesuai apa yang diinginkan SMM ISO 9001:2008 disebabkan oleh karena faktor tangibel dan kenyaman pelayanan masih kurang; kehandalan petugas pelayanan yang masih kurang; masih kurangnya akurasi dan daya tanggap petugas pelayanan; dan masih kurangnya empati aparat, tingkat ketrampilan dan kedislipinan aparat dalam memberikan pelayanan yang masih perlu ditingkatkan, adanya biaya tambahan di luar ketentuan untuk mendapatkan pelayanan, petugas dalam memberikan pelayanan yang masih ada yang kurang ramah.

\section{Saran}

Saran yang sekiranya dapat dilakukan oleh Pemerintah Kota Blitar terutama di bidang pelayanan pembuatan KTP dan KK perlu mengambil langkalangkah sebagai berikut: 1. Perlu adanya regulasi apakah itu berupa peraturan walikota ataupun peraturan daerah yang berisikan tentang adanya transparansi kepada mayarakat terutama persoalan prosedur dan target waktu penyelesaian, dan standar biaya; 2. Kualifikasi SDM aparatur pelayanan pembuatan KTP dan KK. Hal ini diperlukan karena hasil penelitian masih ada yang memandang bahwa aparat pelayanan tidak semuanya ramah, daya tanggap petugas pelayanan masih kurang; 3. Pihak Pemerintah Kota Blitar perlu mengambil langkah untuk meningkatkan kapasitas dan kapabiltas aparatur pelayanan agar profesional dalam memberikan pelayanan kepada publik.

\section{DAFTAR PUSTAKA}

Arikunto, Suharsimi. 2006. Manajemen Penelitian. Jakarta: Rineka Cipta.

Gaspersz, Vincent. 1997. Manajemen Kualitas Dalam Industri Jasa. Jakarta: Gramedia Pustaka.

Gie, The Liang. 1998. Ensiklopedia Administrasi. Jakarta: PT. Agung.

Handayaningrat, Soewarno H. 1996. Pengantar Studi Ilmu Administrasi dan Manajemen. Jakarta: PT.Gunung Agung.

Hasibuan, Melayu. 2001. Organisasi dan Motivasi, Dasar Peningkatan Produktivitas. Jakarta: PT Bumi Aksara

Haryanto, Rohadi. 2003. Kebijakan dan Arah Penyelenggaraan Sistem Administrasi Kependudukan (SAK). Jakarta: Direktorat 
Jenderal Administrasi Kependudukan Departemen Dalam Negeri.

Lembaga Administrasi Negara. 2003. Penyusunan Standar Pelayanan Publik. Jakarta: LAN RI.

Nardiasmo. 2002. Akuntansi Sektor Publik (Edisi Pertama, Cetakan Pertama). Yogyakarta: Andi.

Moenir, H.A.S. 2002. Manjemen Pelayanan Umum di Indonesia. Jakarta: Bumi Aksara.

Nazir, M. 2003. Metode Penelitian. Jakarta: Ghalia Indonesia.

Ndraha, Taliziduhu. 2003. Kybernologi (Ilmu Pemerintahan baru) Jilid I. Jakarta: Rineka Cipta.

Robins, Stephen. 1994. Teori Organisasi, Struktur, Desain dan Aplikasi. Jakarta: Arcan.

Sekaran, Uma. 2006. Methodologi Penelitian Bisnis. Buku 1 dan 2. Jakarta: Salemba Empat, Edisi 4.

Siagian, Sondang P. 1997. Organisasi Kepemimpinan dan Perilaku Administrasi. Jakarta: PT. Gunung Agung.

Siagian, Sondang P. 1998. Manajemen Sumber daya Manusia. Jakarta: PT. Bumi Aksara.

Sianipar. 1998. Pelayanan Prima (Bahan Diklat Prajabatan Golongan II). Jakarta: LAN RI..

Soetopo. 1997. Pelayanan Prima Bahan Diklat Adum. Jakarta: LAN-RI.

Soetopo. 1998. Studi Public Administration. Jakarta: Rineka Cipta.

Steers, Richard M. 1985. Efektivitas Organisasi. Jakarta: Erlangga.

Sugiyono. 2003. Metode Penelitian Administrasi (Edisi Revisi Cetakan Ketga belas). Bandung: CV. Alfabeta.

Sukamto, Soeryono. 1983. Kamus Sosiologi. Jakarta: Rajawali Indonesia.

Tjiptono dan Anastasia, Diana. 2002. Total Quality Management. Yogyakarta: Andi.

Tjiptono, Fandy. 2001. Manajemen Jasa. Yogyakarta: Andi.

Umar. 2000. Metodologi Penelitian. Jakarta: Rineke Cipta.

Wasistiono, Sadu.2002. Menata Ulang Kelembagaan Pemerintah Kecamatan. Bandung: Citra Pindo.

Zeithaml, Valarie A, dkk. 199., Delivlering Quality Service Balancing Customer Perceptions and Expections. New York: The Free Press A Divisions of Macmilan Inc. 